\title{
The role of accent imitation in sensorimotor integration during processing of intelligible speech
}

\author{
Patti Adank 1,2*, Shirley-Ann Rueschemeyer ${ }^{2,3}$ and Harold Bekkering ${ }^{2}$ \\ ${ }^{1}$ Department of Speech, Hearing and Phonetic Sciences, Division of Psychology and Language Sciences, University College London, London, UK \\ ${ }^{2}$ Donders Institute for Brain, Cognition and Behaviour, Radboud University Nijmegen, Nijmegen, Netherlands \\ ${ }^{3}$ Department of Psychology, University of York, York, UK
}

\section{Edited by:}

Hans-Jochen Heinze, University of Magdeburg, Germany

Reviewed by:

Shanqing Cai, Boston University, USA

Marc Sato, CNRS and Grenoble

University, France

${ }^{*}$ Correspondence:

Patti Adank, Department of Speech, Hearing and Phonetic Sciences,

Division of Psychology and

Language Sciences, University

College London, Room 323,

Chandler House, 2 Wakefield St.,

London, WC1N 1PF, UK

e-mail:p.adank@ucl.ac.uk
Recent theories on how listeners maintain perceptual invariance despite variation in the speech signal allocate a prominent role to imitation mechanisms. Notably, these simulation accounts propose that motor mechanisms support perception of ambiguous or noisy signals. Indeed, imitation of ambiguous signals, e.g., accented speech, has been found to aid effective speech comprehension. Here, we explored the possibility that imitation in speech benefits perception by increasing activation in speech perception and production areas. Participants rated the intelligibility of sentences spoken in an unfamiliar accent of Dutch in a functional Magnetic Resonance Imaging experiment. Next, participants in one group repeated the sentences in their own accent, while a second group vocally imitated the accent. Finally, both groups rated the intelligibility of accented sentences in a post-test. The neuroimaging results showed an interaction between type of training and pre- and post-test sessions in left Inferior Frontal Gyrus, Supplementary Motor Area, and left Superior Temporal Sulcus. Although alternative explanations such as task engagement and fatigue need to be considered as well, the results suggest that imitation may aid effective speech comprehension by supporting sensorimotor integration.

Keywords: imitation, fMRI, speech, accent, sensorimotor

\section{INTRODUCTION}

In everyday communication, humans have to deal with a variety of challenging listening situations, such as the presence of background noise, poor telephone connections, or unfamiliar accents. Recent studies have investigated cognitive and neural mechanisms underlying the ability to process speech effectively in such challenging listening situations (Davis and Johnsrude, 2003; Rodd et al., 2005, 2010; Obleser et al., 2007, 2011; Adank and Devlin, 2010; Obleser and Kotz, 2010; Peelle et al., 2010; Adank, 2012). The aforementioned studies have established that effective speech comprehension recruits areas involved in speech perception including left Superior Temporal Sulcus (STS), areas involved in linguistic and articulatory processes including left Inferior Frontal Gyrus (IFG), areas involved in speech production including Precentral Gyrus and Supplementary Motor Area (SMA).

There is growing consensus that cortical regions associated with speech production, such as ventral premotor cortex, IFG, SMA/pre-SMA, and primary motor cortex play an active and essential role in effective speech comprehension (Skipper et al., 2006; D'Ausilio et al., 2009; Londei et al., 2009; Callan et al., 2010; Tremblay and Small, 2011; Adank, 2012). Despite this emerging agreement (but see Venezia et al., 2012), much is still unclear about precisely how speech motor and premotor regions contribute to the comprehension process.

Recent theories suggests that mental simulation of perceived actions may aid listeners when predicting upcoming speech signals (Wilson and Knoblich, 2005; Pickering and Garrod, 2007).
Simulation theories of action perception argue that observing actions results in the automatic generation of motor plans required to perform these actions. The motor plans are used to produce a forward model of the incoming action. These forward models use information about the movement properties of muscles to generate a simulated course of movement in parallel with, or even in anticipation of, the perceived movement (Grush, 2004). Any discrepancy between the simulated movement from the forward model and the real-world movement results in prediction errors and leads to corrective commands. This type of forward model serves to anticipate others' (speech) actions as if they were produced by the observer (Locatelli et al., 2012). Forward models thus, generate a series of predictions that may be used as disambiguating information in situations of when action perception is made more difficult due to noisy or ambiguous observing conditions (Wilson and Knoblich, 2005; Pickering and Garrod, 2007). For speech, these type of conditions involve listening to speech in the presence of background noise, or listening to someone speak with an unfamiliar regional accent (Adank et al., 2009).

Some propose that the prediction signal generated by the forward models is optimized for the type of actions the observers have had experience executing themselves (Knoblich and Sebanz, 2006; Grafton, 2009). Behavioral evidence for this prediction comes from a study on basketball players by Aglioti et al. (2008). Aglioti et al. compared elite basketball players (experts at observing the action and also at performing the action) with a control group (basketball referees; experts at observing the action but not playing themselves) on how effectively each group could judge 
whether a basketball would be thrown in the basket. They showed that being experienced in performing an action such as throwing a basketball allows one to efficiently predict the outcome of other players throwing a basketball.

For speech, we recently found that short-term experience with speaking in an unfamiliar regional accent helps comprehension of sentences spoken in that accent (Adank et al., 2010). Adank et al.'s participants listened to sentences spoken in an unfamiliar accent in background noise in a pre-test phase and verbally repeated key words. Next, participants were divided into six groups and either received no training, listened to sentences in the unfamiliar accent without speaking, repeated the accented sentences in their own accent, listened to and transcribed the accented sentences, listened to and imitated the accented sentences, or listened to and imitated the accented sentences without being able to hear their own vocalizations. Post-training measures showed that participants who imitated the speaker's accent could repeat key words in poorer signal-to-noise ratios (i.e., under more challenging listening conditions) than participants who had not imitated the accent. Adank et al.'s results demonstrate that having experience with speaking in a specific way (i.e., in an unfamiliar accent) can positively affect speech processing by optimizing comprehension of sentences spoken in a similar way.

The neural underpinnings of the optimizing effect of experience with performing an action on action perception have been investigated a several fMRI experiments (Calvo-Merino et al., 2005; Wilson and Iacoboni, 2006; Lahav et al., 2007). CalvoMerino et al. (2005) studied professional dancers and compared neural activity when male and female dancers viewed dance moves that were performed by their own gender (i.e., moves they would perform when dancing themselves), compared to other moves performed by the other gender (i.e., moves they would always observe, but not perform, when dancing themselves). Calvo-Merino's design allowed them to separate brain responses related to dance motor representation from those related to visual knowledge about the observed moves. Left dorsal premotor cortex, left inferior parietal sulcus, and right cerebellum showed a higher Blood Oxygenated-Level Dependent (BOLD-) response for dance moves they would perform themselves than for observed moves.

Lahav et al. (2007) trained non-musicians in playing several simple melodies on the piano. Participants were scanned while listening to pieces they had learnt to play, plus pieces they had not learnt. An increased BOLD-response was found in bilateral IFG, the posterior middle premotor region and the inferior parietal lobule (IPL) (Supramarginal gyrus and Angular gyrus) bilaterally and left cerebellum.

Finally, Wilson and Iacoboni tested neural responses for 5 native and 25 non-native speech sounds varying in how easy they were to produce for their native American-English speaking participants. They report increased activation in bilateral superior temporal areas for foreign speech sounds that are more difficult to produce. No correlations were found between the ease with which the foreign sounds could be produced in speech motor areas. Nevertheless, in a region-of-interest analysis, they report that the BOLD-response in premotor cortex, a speech motor area, was elevated for listening to foreign speech sounds compared to native speech sounds. The results from Wilson and Iacoboni thus, contradict the expectation that having had more experience with a motor action (which is the case for native speech sounds) activates motor areas to a higher degree. However, Wilson did not explicitly evaluate how experience with producing the foreign speech sounds affected brain activation when listening to those speech sounds. Thus, it remains unclear how speech motor experience affects neural activation during speech comprehension.

The present study will examine how motor experience with imitating a novel accent affects the activation of cortical areas associated with speech perception and production when subsequently listening to the accented speech in background noise. Based on Adank et al.'s behavioral study, we hypothesized that speech imitation experience supports speech comprehension through the integrating of information from specific speech perception and production areas.

We mapped out the neural bases associated with increased robustness of speech comprehension after imitating an unfamiliar accent and after repeating the accented speech in one's own accent. Two groups of listeners were scanned using an adapted version of the staircase procedure described in Adank et al. (2010). In a pre-test, participants were examined on their comprehension of sentences spoken in an unfamiliar accent in background noise. Next, one group of participants repeated a series of accented sentences in their own accent, while the second group vocally imitated the sentences in the unfamiliar accent in a training session. Finally, both groups were tested again on their comprehension of accented speech in background noise. If imitation supports sensorimotor integration, we expected a different pattern of activation of cortical areas associated with either speech comprehension or speech production for listeners who have had experience with imitating the unfamiliar accent during the training session. We focused on three left-lateralized regions, namely posterior STS, IFG, and SMA, all of which have been associated with speech perception and speech production tasks (for STS: Scott et al., 2000; Blank et al., 2002; Narain et al., 2003; Crinion and Price, 2005; Tremblay and Gracco, 2009, for IFG: Davis and Johnsrude, 2003; Tremblay and Gracco, 2009; Adank and Devlin, 2010, for SMA: Alario et al., 2006; Wong et al., 2008; Fridriksson et al., 2009).

\section{MATERIALS AND METHODS PARTICIPANTS}

We tested 36 participants $(23 \mathrm{~F}$ and $13 \mathrm{M}$, mean 21.8 years, $S D$ 2.9 years, range $18-29$ years). All participants were right-handed, native speakers of Dutch, with no history of oral or written language impairment, or neurological or psychiatric disease. All gave written informed consent and were paid for their participation. The study was approved by the local ethics committee of the Radboud University Nijmegen. Four participants were excluded from further analysis: one participant (F) originally allocated to the imitation group was excluded as the second run was not collected due to technical difficulties, another participant allocated to the imitation group $(\mathrm{M})$ was excluded due to an abnormality in his structural scan, a repeat group participant (M) was excluded as his scan was interrupted due to him feeling unwell, and a final participant $(\mathrm{F})$ in the repeat group was excluded due to poor 
performance on the behavioral task; her results showed more than $50 \%$ missed responses. All analyses were run on the results from the remaining 32 participants. The repeat group consisted of 15 participants (9F and 6M, mean 21.6 years, SD 3.2 years, range 18-29 years) and the imitation group consisted of 17 participants (10F and 6M, mean 22.2 years, SD 2.8 years, range $18-28$ years).

\section{STIMULUS MATERIAL}

The test stimulus set consisted of 96 sentences (see Table A1 in the Appendix) that were taken from the speech reception threshold (SRT) corpus (Plomp and Mimpen, 1979). This corpus has been widely used for assessing intelligibility of different types of stimuli, for example, for foreign-accented speech (Van Wijngaarden et al., 2002). Sentences in the SRT corpus are designed to resemble short samples of conversational speech. All consist of maximally eight or nine syllables and do not include words longer than three syllables. The 48 sentences used in the training (listed in Table A2) were taken from an earlier study on comprehension of accented speech (Adank et al., 2012) and produced by the same speaker as the 96 test sentences. Finally, 30 sentences were recorded in Standard Dutch and used in a hearing pre-test (cf. Table A3).

All sentences were spoken by a single female speaker of Standard Dutch. The test sentences were recorded in both Standard Dutch and an unfamiliar, novel accent. The training sentences were recorded in the novel accent only. The novel accent was created by instructing the speaker to read sentences with an adapted orthography (see also Adank et al., 2010). This accent was designed to sound different from Standard Dutch and not intended to replicate an existing Dutch accent. The orthography was systematically altered to achieve changes in all 15 Dutch vowels as listed in Table 1. Only vowels bearing primary or secondary stress were included in the orthography conversion. An example of a sentence in Standard Dutch and a converted version is

Table 1 | Intended vowel conversions for obtaining the novel accent.

\begin{tabular}{|c|c|}
\hline Orthography & Phonetic (IPA) \\
\hline$a \rightarrow$ aa & /a/ $\rightarrow$ /a:/ \\
\hline $\mathrm{aa} \rightarrow \mathrm{a}$ & /a:/ $\rightarrow / \mathrm{a} /$ \\
\hline$e \rightarrow e e$ & $|\varepsilon| \rightarrow \mid \mathrm{e} /$ \\
\hline $\mathrm{ee} \rightarrow \mathrm{e}$ & $|\mathrm{e}: / \rightarrow| \varepsilon \mid$ \\
\hline $\mathrm{i} \rightarrow \mathrm{ie}$ & /I/ $\rightarrow$ /i:/ \\
\hline $\mathrm{ie} \rightarrow \mathrm{i}$ & /i:/ $\rightarrow$ /l/ \\
\hline $\mathrm{o} \rightarrow \mathrm{oo}$ & /o/ $\rightarrow$ /O:/ \\
\hline $\mathrm{oO} \rightarrow \mathrm{O}$ & /O:/ $\rightarrow$ /o/ \\
\hline $\mathrm{uu} \rightarrow \mathrm{u}$ & $\left|y_{:} / \rightarrow\right| Y \mid$ \\
\hline $\mathrm{u} \rightarrow \mathrm{uu}$ & $|Y| \rightarrow\left|Y_{\Delta}\right|$ \\
\hline $\mathrm{oe} \rightarrow \mathrm{u}$ & $/ \mathrm{u} / \rightarrow \mathrm{Y}$ \\
\hline $\mathrm{eu} \rightarrow \mathrm{u}$ & $|\phi| \rightarrow|Y|$ \\
\hline $\mathrm{au} \rightarrow \mathrm{oe}$ & $/ \mathrm{ou} / \rightarrow / \mathrm{u} /$ \\
\hline $\mathrm{ei} \rightarrow \mathrm{ee}$ & $/ \varepsilon i / \rightarrow$ le:/ \\
\hline $\mathrm{ui} \rightarrow \mathrm{uu}$ & /œy/ $\rightarrow / \mathrm{y}: /$ \\
\hline
\end{tabular}

The left column shows the altered orthography in Standard Dutch, and the right column shows the intended change in pronunciation of the vowel in broad phonetic transcription, using the International Phonetic Alphabet (IPA, 1999). given below, including a broad phonetic transcription using the International Phonetic Alphabet (IPA, 1999):

Standard Dutch: "De bal vloog over de schutting" /də bal flox o:fər do sxytin/

[The ball flew over the fence]

After conversion: "De baal flog offer de schuuttieng" /də ba:1 flo:x ofər də sxy:tin/

The stimulus materials used in the scanner was created as follows. The sentences in background noise were created by adding continuous speech-shaped noise to the accented sentences in quiet at so that the final signal-to-noise ratio (SNR) was set to $-2 \mathrm{~dB}, 0 \mathrm{~dB},+2 \mathrm{~dB},+4 \mathrm{~dB},+6 \mathrm{~dB},+8 \mathrm{~dB},+10 \mathrm{~dB},+12 \mathrm{~dB}$, $+14 \mathrm{~dB}$, or $+16 \mathrm{~dB}$, thus, resulting in 10 versions for each sentence. Speech-shaped noise was added using Matlab (Mathworks Inc.). An acoustically matched-yet unintelligible-baseline version of each sentence was created by spectrally rotating (Blesser, 1972) and time-reversing the sentence, using Praat (Boersma and Weenink, 2003). No noise was added to the baseline sentences. Sentences in all conditions were subsequently saved at $70 \mathrm{~dB}$ SPL.

\section{MRI DATA ACQUISITION}

Whole-brain imaging was performed at the Donders Centre for Brain, Cognition and Behavior, Centre for Cognitive Neuroimaging, at a 3T MR scanner (Magnetom Trio, Siemens Medical Systems, Erlangen, Germany), in Nijmegen, The Netherlands. The sentences were presented over soundattenuating ( $~ 30 \mathrm{~dB}$ SPL) electrostatic headphones (MRConFon, Magdeburg, Germany) during continuous scanner acquisition (GE-EPI, echo time $35 \mathrm{~ms}$; 32 axial slices; voxel size $3.5 \times 3.5 \times 3.5 \mathrm{~mm}$, slice thickness $3 \mathrm{~mm}$, inter-slice gap $0.5 \mathrm{~mm}$; field of view $224 \mathrm{~mm}$; flip angle 70 ). All functional images were acquired in two runs. Functional scans were obtained every $2 \mathrm{~s}$ in a continuous scanning paradigm (TR $2 \mathrm{~s}$ ). Listeners watched a fixation cross that was presented on a screen and viewed through a mirror attached to the head coil. After the acquisition of functional images, a high-resolution structural scan was acquired (T1-weighted MP-RAGE, 192 slices, echo time $3.93 \mathrm{~ms}$; field of view $256 \mathrm{~mm}$, slice thickness $1 \mathrm{~mm}$ ). Finally, a diffusion-weighted scan was acquired with 68 directions (not included in the present analysis). Total scanning time was around $60 \mathrm{~min}$.

\section{PROCEDURE}

The experiment had a mixed-subject design with two groups (Figure 1): Repeat or Imitate. Participants were randomly

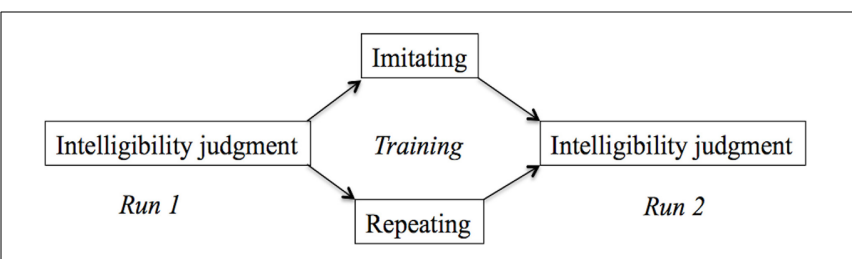

FIGURE 1 | Tasks in the three phases of the experiment. Both groups performed an intelligibility judgment in the first run. Subsequently, the imitation group imitated a series of sentences in an unfamiliar accent, while the repeat group repeated sentences in their own accent. Finally, all participants performed the intelligibility judgment task again. 
allocated to the Repeat or Imitation group. Imaging data was collected in two runs and participants performed a training task in between these runs. Before the start of the scanning session, participants completed a hearing test in a quiet room. This test established the SRT as described in Plomp and Mimpen (1979) for sentences spoken in Standard Dutch by the same female speakers as used for the test in the scanner. Using a similar procedure as in (Adank et al., 2010), participants responded by repeating back what they had heard and the experimenter scored key words (see Table A1 in the Appendix). In this "standard" version, of the SRT, participants were presented the first sentence at $+10 \mathrm{~dB}$ SNR. If they correctly repeated more than two out of four keywords, the next sentence was played at $+2 \mathrm{~dB}$ SNR, if they got more than two key words in this sentence correct, the next sentence was played at $-6 \mathrm{~dB}$. This procedure continued until the participant either got two keywords right, or if he or she got fewer than two keywords right. If they repeated two keywords correctly, the next sentence was played at the same SNR as the previous sentence, while the SNR was increased with $+2 \mathrm{~dB}$ if fewer than two keywords were repeated. If the participant than got more than two keywords right, the SNR decreased in steps of $-2 \mathrm{~dB}$. This staircase procedure was repeated for 30 sentences (Table A3). The final SNR, or SRT, was calculated as the average across all instances for which a reversal occurred, following Adank et al. (2010) and Plomp and Mimpen (1979). A reversal occurs whenever the SNR changed direction (e.g., from $0 \mathrm{~dB}$ SNR to +2 $\mathrm{db} \mathrm{SNR}$, or to $-2 \mathrm{~dB}$ SNR). The participants showed an average SRT of $-3.69 \mathrm{~dB}(0.95 \mathrm{~dB} S D)$, indicating that their hearing was in the normal range for participants with normal hearing (Plomp and Mimpen, 1979).

While in the scanner, participants in both groups performed an intelligibility judgment in the first run. Following the procedure in Adank et al. (2010), participants in the repeat group were instructed to listen to each accented sentence and then to repeat it in their own accent, without imitating the accent. Participants were explicitly instructed not to imitate the speaker's accent. If participants imitated the accent, they were reminded by the experimenter to repeat the sentence in Standard Dutch. Participants repeated 48 sentences. In the imitation group, participants were instructed to imitate vocally the precise pronunciation of the accented sentence. If participants repeated the sentence in their own accent, the experimenter instructed to imitate the accent as they heard it spoken. Participants imitated 48 sentences during the training and training was not attested using a formal scoring device. The scanner was turned off during the training phase. Next, the second run commenced and participants performed the intelligibility judgment task from run 1 for another series of accented sentenced. A total of 96 test sentences was presented across the two runs, plus 48 training sentences in between runs. Per run, 24 acoustically-matched baseline stimuli and 48 test sentences were presented. The distribution of the test sentences and baseline stimuli (which were created based on the 96 test sentences) were counterbalanced across runs and participants.

A single trial in the intelligibility judgment task began with a tone signal of $250 \mathrm{~Hz}$ with a duration of $200 \mathrm{~ms}$, followed by a pause of $200 \mathrm{~ms}$, followed by the presentation of a sentence. After the sentence was presented, participants judged its intelligibility, using a button-box with four buttons (one per finger) that they were holding in their right hand. If they found the sentence completely unintelligible, they pressed with their index finger (score 1), if they found the sentence slightly more intelligible they pressed the button under their middle finger (score 2), if they found the sentence intelligible they pressed with their ring finger (score 3 ) and if they found the sentence very intelligible they pressed the button under their little finger (score 4). This procedure was the same across participants. The SNR of the following sentence depended on the score of the previous sentence. If the participant had rated a specific sentence as 1 or 2 , the next sentence was played at an easier (higher) SNR, and if the participant had rated a specific sentence as 3 or 4 , the next sentence was played at a less favorable SNR. For instance, if a participant heard a sentence with a SNR of $+4 \mathrm{~dB}$ and rated the sentence as unintelligible (score 2), then SNR for the next sentence was increased with $2 \mathrm{~dB}$ and the next sentence was presented at $+6 \mathrm{~dB}$. Alternatively, if a participant heard a sentence with a SNR of $+4 \mathrm{~dB}$ and rated the sentence as very intelligible (score 4 ), then SNR for the next sentence was decreased with $2 \mathrm{~dB}$ and the next sentence was presented at $+2 \mathrm{~dB}$. Each run started with a sentence presented at $+10 \mathrm{~dB}$. The SNR decreased in steps of $2 \mathrm{~dB}$ until reaching $-2 \mathrm{~dB}$ SNR and increased in steps of $2 \mathrm{~dB}$ up to $+16 \mathrm{~dB}$ SNR. If these limits were reached, the SNR stayed the same until the participant pressed 3 or 4 (for $+16 \mathrm{~dB}$ ) or 1 or 2 (for $-2 \mathrm{~dB}$ ). As in the behavioral test outside the scanner, SRT was calculated as the average across all instances for which a reversal occurred. This procedure was identical across both runs. Intensity of stimulus presentation was set at a comfortable level for each participant in a familiarization session in which six sentences in Standard Dutch in quiet spoken by the same speaker (not included in the both runs experiment) were presented while the scanner was running. Stimulus presentation was performed using Presentation (Neurobehavioral Systems, Albany, CA), running on a Pentium 4 with $2 \mathrm{~GB}$ RAM, and a $2.8 \mathrm{GHz}$ processor. The two runs plus training lasted $\sim 40 \mathrm{~min}$.

\section{DATA PROCESSING}

The neuroimaging data were pre-processed and analyzed using SPM8 (Wellcome Imaging Department, University College London, London, UK). The first four volumes of every functional run from each participant were excluded from the analysis to minimize T1-saturation effects. Next, the image time series were spatially realigned using a least-squares approach that estimates six rigid-body transformation parameters (Friston et al., 1995) by minimizing head movements between each image and the reference image, that is, the first image in the time series. Next, the time series for each voxel was temporally realigned to acquisition of the middle slice. Subsequently, images were normalized onto a custom Montreal Neurological Institute (MNI)aligned EPI template (standard in SPM8) using both linear and non-linear transformations and resampled at an isotropic voxel size of $2 \mathrm{~mm}$. All participants' functional images were smoothed using an $8 \mathrm{~mm}$ FWHM Gaussian filter. Each participants' functional image was processed using a unified segmentation procedure as implemented in SPM8. After segmentation of the T1 structural image (using the unified segmentation model) 
and co-registration to the mean functional image (Ashburner and Friston, 1997), functional images were spatially normalized into standard stereotaxic space of the MNI using segmentation parameters of the T1 structural image. A high-pass filter was applied with a $0.0078 \mathrm{~Hz}(128 \mathrm{~s})$ cut-off to remove low-frequency components from the data, such as scanner drifts. The fMRI time series were analyzed within the context of the General Linear Model using an event-related approach, including an autoregressive AR (1) model during Classical (ReML) parameter estimation.

Three events of interest were identified and entered into a subject-specific General Linear Model: acoustically matched baseline sentences (Baseline), Unintelligible Speech (i.e., all sentences rated 1 or 2 by the participant), Intelligible Speech (i.e., all sentences rated 3 or 4 by the participant) for each run. Parameter estimates were calculated for each voxel, and contrast maps were constructed for each participant. The statistical model also considered six separate covariates describing the headrelated movements (as estimated by the spatial realignment procedure). Linear-weighted contrasts were used to specify the main contrasts.

Intelligibility (having two levels: Intelligible Speech and Baseline), Run (Run 1 or Run 2), and Group (Repeat and Imitate) were analyzed in a $2 \times 2 \times 2$ mixed ANOVA design, with Run as a within-subject and Group as a between-subject factor. We first identified areas showing a higher BOLD response for Intelligible Speech than for Baseline. Second, we identified areas that showed a higher BOLD-response as a result of having imitated during the training. We compared the activation across both runs for both groups. We used the following contrast to identify areas that showed a higher BOLD-response for the Imitate group than the Repeat group by directly comparing the second to the first run for each group: [Intelligible speech Imitation Group Run $2>$ Intelligible speech Imitation Group Run 1] > [Intelligible speech Repeat Group Run $2>$ Intelligible speech Repeat Group Run 1] (in short: [Imitation Run $2>1$ ] > [Repeat Run $2>1$ ]). Second, we identified areas showing a higher BOLD-response as a result of having repeated vs. imitated during the training using the contrast: [Intelligible speech Repeat Group Run $2>$ Intelligible speech Repeat Group Run 1] > [Intelligible speech Imitation Group Run $2>$ Intelligible speech Imitation Group Run 1] (in short: [Repeat Run $2>1$ ] $>$ [Imitation Run $2>1$ ]). We also tested the contrasts [Imitate Run $2>$ Run 1] and [Repeat Run $2>$ Run 1] to get a general idea of areas that showed increases in BOLD-response across runs for both groups.

Significant activations in the whole-brain analysis were assessed with a Family Wise Error (FWE) correction for multiple comparisons $(p<0.05)$, in combination with a minimal cluster extent of 20 voxels. Finally, anatomical localization was performed using the Anatomy toolbox in SPM8 (Eickhoff et al., 2005) and verified with MRICRON using the ch2 template in MNI space (Rorden and Brett, 2000).

\section{RESULTS \\ BEHAVIORAL RESULTS}

A repeated-measures ANOVA with Group (Repeat or Imitate) and Run (1 or 2) on the SRT value in $\mathrm{dB}$ per run (Figure 2)

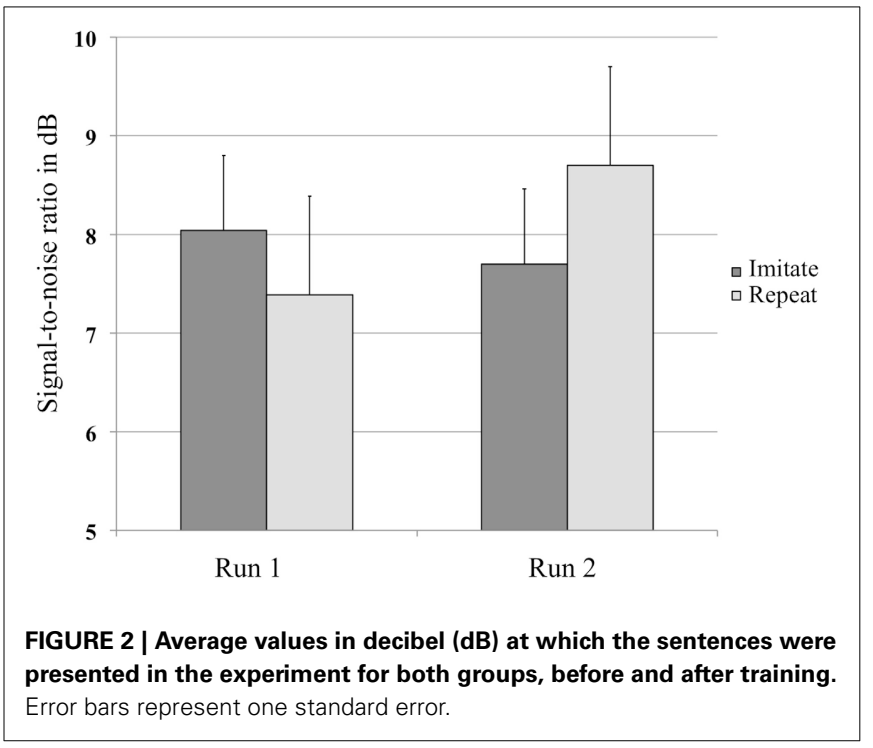

revealed no main effects, but did show an interaction between Run and Group $\left[F_{(1,30)}=6.21, p=0.018, \eta_{p}^{2}=0.17\right]$. The absence of a main effect of Run indicated that both groups of listeners judged the sentence materials to be equally intelligible when played at similar SNRs. The presence of an interaction between Run and Group indicates that listeners in both groups were affected differently by the training. Two post-hoc analyses showed a marginally significant trend for the repeat group to require more favorable SNRs in the second run $\left[t_{(14)}=-2.033\right.$, $p=0.061]$, while no such trend was found for the imitate group $\left[t_{(16)}=0.946, p=0.358\right]$.

\section{NEUROIMAGING RESULTS}

Table 2 and Figure 2 show the network of areas involved in processing intelligible speech (the contrast Intelligibility included all stimuli that had been rated as 3 or 4 in the intelligibility judgment test) vs. the acoustically matched baseline. Intelligible speech was associated with higher BOLD values with peak coordinates in left and right anterior and posterior STS, left IFG, left insula, and SMA.

We tested the contrasts [Imitation Run 2 $>1$ ] $>$ [Repeat Run $2>1$ ] and [Repeat Run $2>1$ ] $>$ [Imitation Run $2>1$ ] to probe for areas showing an effect of training in the second run for both groups (see Table 2 and Figure 3 ) in a wholebrain analysis. The areas showing an increased BOLD-response for the contrast [Imitation Run $2>1$ ] $>$ [Repeat Run $2>1$ ] effect included left STS, an area in left IFG, and a cluster in left SMA. For the reverse contrast [Repeat Run $2>1$ ] $>$ [Imitation Run $2>1$ ] no significant clusters were found. However, at a less stringent significance level of $p<0.001$, we found two clusters in left and right Supramarginal Gyrus (SMG) at $[-62-3836]$ (157 voxels) and [60 -42 22] (50 voxels). Finally we found no supra-threshold voxels for the contrast [Repeat Run $2>$ Run 1], while for [Imitate Run $2>$ Run 1] significant clusters were found in MTG bilaterally, left STG, SMA, bilateral Anterior Insula, Right Temporal Pole, and left Fusiform Gyrus. 
Table 2 | Activation for peaks separated by at least $8 \mathbf{~ m m}$ for the whole-brain analysis for the contrasts [Intelligibility $>$ Baseline], [Imitation Run $2>1$ ] > [Repeat Run $2>1$ ], and [Run 1] > [Run 2].

\begin{tabular}{|c|c|c|c|c|}
\hline Location & $\mathrm{mm}^{3}$ & $t$ & Equivalent $Z$ & MNI \\
\hline \multicolumn{5}{|c|}{ [INTELLIGIBILITY > BASELINE] } \\
\hline Left STS & 966 & 10.03 & $\operatorname{lnf} *$ & $-62-324$ \\
\hline Left STG & & 6.46 & 5.97 & $-58-4-8$ \\
\hline Left MTG & & 5.31 & 5.02 & $-60-16-8$ \\
\hline Left IFG (Triangularis) & 306 & 6.70 & 6.17 & -501824 \\
\hline Left IFG (Orbitalis) & 374 & 6.61 & 6.09 & $-4628-4$ \\
\hline Left Insula & & 6.00 & 5.60 & $-3622-4$ \\
\hline Right STG & 250 & 5.94 & 5.55 & $56-20-6$ \\
\hline Right STG & & 5.83 & 5.46 & $602-12$ \\
\hline Left SMA & 71 & 5.32 & 5.03 & -21060 \\
\hline \multicolumn{5}{|c|}{ [IMITATION RUN $2>1$ ] > [REPEAT RUN $2>1]$} \\
\hline Left STS & 750 & 8.47 & 7.49 & $-62-322$ \\
\hline Left MTG & & 6.89 & 6.31 & $-58-20-8$ \\
\hline Left STS & & 5.44 & 5.13 & $-58-8-8$ \\
\hline Left IFG (Triangularis) & 164 & 6.42 & 5.94 & -521826 \\
\hline Left SMA & 20 & 5.30 & 5.01 & -41064 \\
\hline Left IFG (Orbitalis) & 26 & 5.28 & 4.99 & $-4626-4$ \\
\hline \multicolumn{5}{|c|}{ [IMITATE RUN 2 > RUN 1] } \\
\hline Left MTG & 6131 & 15.79 & $\operatorname{lnf}$ & $-58-342$ \\
\hline Left STG & & 14.18 & $\operatorname{lnf}$ & $-58-2-8$ \\
\hline Left anterior insula & & 12.66 & Inf & $-3024-4$ \\
\hline Left SMA & 1448 & 11.90 & $\operatorname{lnf}$ & -42046 \\
\hline R ACC & & 6.63 & 6.11 & 123028 \\
\hline L ACC & & 5.67 & 5.32 & -83222 \\
\hline Right STG & 1512 & 11.42 & $\operatorname{lnf}$ & $602-10$ \\
\hline Left anterior insula & & 10.89 & $\operatorname{lnf}$ & $3224-2$ \\
\hline Right TP & & 9.06 & $\operatorname{lnf}$ & $5212-18$ \\
\hline White matter & 680 & 10.49 & Inf & -1466 \\
\hline White matter & 375 & 9.33 & $\operatorname{lnf}$ & 12100 \\
\hline Right STG & 47 & 6.11 & 5.69 & $46-362$ \\
\hline White matter & 45 & 5.62 & 5.28 & $-4-24-18$ \\
\hline White matter & & 4.80 & 4.58 & $-6-20-10$ \\
\hline Left FFG & 23 & 5.51 & 5.20 & $-38-38-20$ \\
\hline
\end{tabular}

Coordinates in MNI standard space. ACC, Anterior Cingulate Cortex; FFG, Fusiform Gyrus; IFG, Inferior Frontal Gyrus; MTG, Middle Temporal Gyrus; SMA, Supplementary Motor Area; STG, Superior Temporal Gyrus; STS, Superior Temporal Gyrus; TP, Temporal Pole. *Inf denotes Equivalent $Z>10.0$.

\section{DISCUSSION \\ MAIN FINDINGS}

We investigated the neural bases associated with increased robustness of speech comprehension after imitating an unfamiliar accent and after repeating the accented speech in one's own accent. The aim of the study was to establish the effect of short term-experience with imitating accented speech on the activation of cortical areas associated with speech perception and production when subsequently listening to the accent in background noise.

Based on previous studies on the role of motor experience, it was expected that motor experience with speaking in a novel unfamiliar accent action would result in a changed activation pattern brain areas associated with speaking and listening to speech, including left IFG, STS, and SMA. Previous studies on motor experience in general action processing (Calvo-Merino et al., 2005; Lahav et al., 2007) predicted that experience with performing a motor act (such as performing a dance move in Calvo-Merino et al.) increased activation in motor areas associated with performing that act while participants passively observed the act. However, a previous study on the effect of long-term speech production experience on speech sound perception (Wilson and Iacoboni, 2006) found that activation in premotor cortex was elevated for listening to foreign speech sounds.

Our results show that motor experience with accented speech leads to increased activation in speech perception and speech motor areas during subsequent comprehension of that accent. Areas in left STS, left IFG, and left SMA showed an interaction between run and group: they were more active during the second run for the imitation group compared to the difference between the first and second run for the repeat group. This effect was supported by a significant behavioral interaction between Run and Group.

Interestingly, these results are largely in line with previous studies that established the effect of perceptual experience with unfamiliar or distorted speech streams on neural activation during comprehension (Adank and Devlin, 2010; Eisner et al., 2010). Both studies monitored participants' neural activations while they perceptually adapted to distorted speech. Adank and Devlin presented participants with 64 sentences spoken by at a normal speed, before playing 64 sentences that had been artificially speeded up (time-compressed speech) to $45 \%$ of their original duration (Dupoux and Green, 1997). Participants performed a speeded sentence-verification task (i.e., deciding whether a sentence such as "Cars have four wheels" is true or false). When presented with the time-compressed sentences, performance on the sentence-verification task initially deteriorated sharply, but it quickly improved, signaling successful perceptual adaptation. Four cortical areas showed a pattern in the BOLD-activations in line with the behavioral results: one area in left ventral premotor cortex, two left lateralized areas in STG/STS, and one right-lateralized area in STG/STS. Eisner et al. studied the cortical changes in activity related to learning to perceptually adapt to noise-vocoded speech (Shannon et al., 1995). They included two types of distortion: one that was learnable and another was not Eisner et al. found that activity in left IFG correlated positively with individual variation in working memory scores, and that left IFG and left STS were sensitive to the extent to which the stimulus displayed learnable variation.

Nevertheless, a difference between the present study and Adank and Devlin's is that Adank and Devlin used an online learning design. They monitored neural responses as participants perceptually adapted. In the present study, we used an offline design: we did not monitor participants' neural responses during the training, to avoid problems with head motion during speaking. Consequently, it is possible that left IFG, STS, and SMA were even more active during the training phase for the imitation group. Adank and Devlin report that areas that showed an increase in their BOLD-response when participants were first 


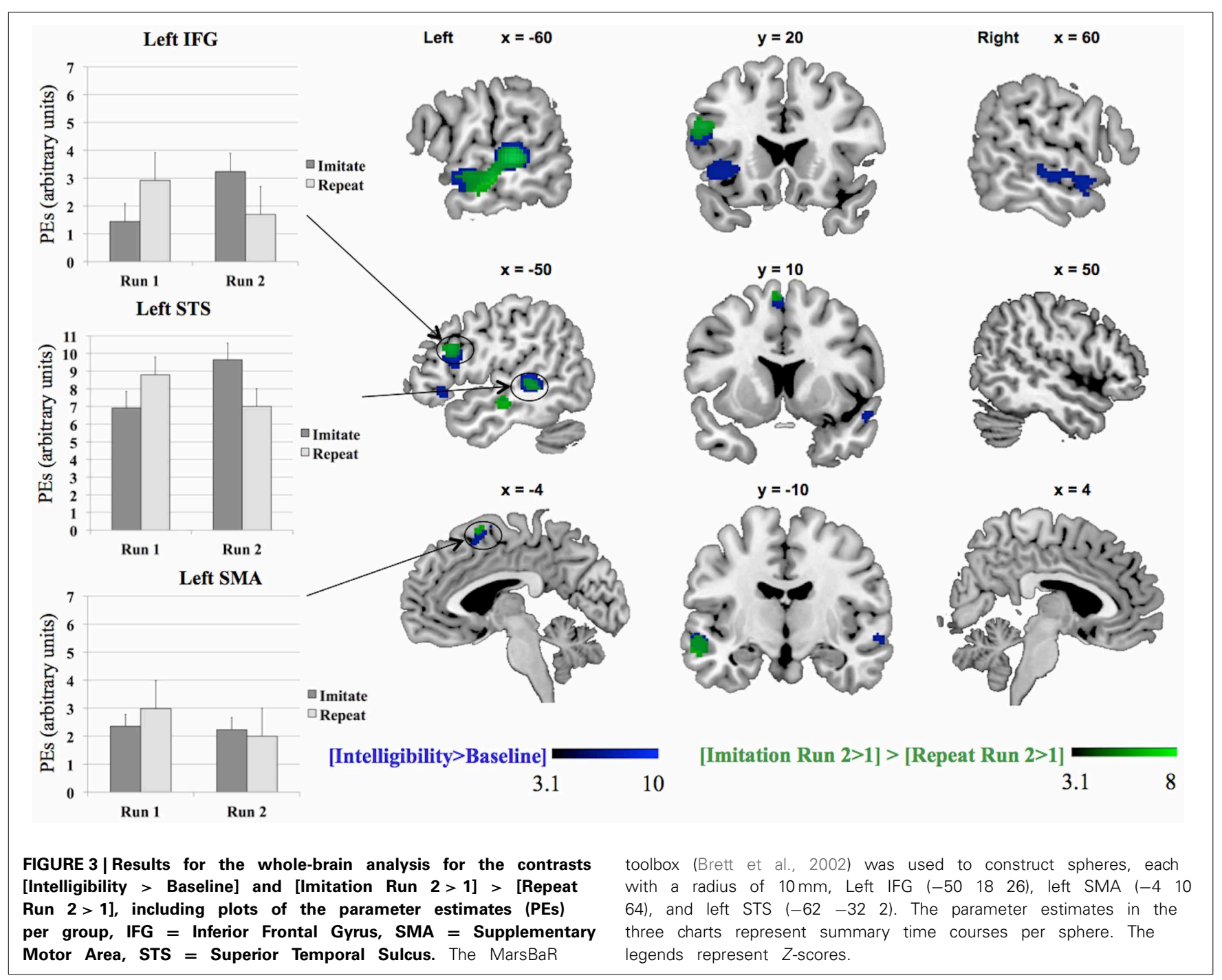

confronted with the distortion (time-compressed sentences) in the speech signal also remained more active after participants had adapted. Thus, speech perception and speech production regions continued to be active when the listening conditions remained challenging.

However, others have suggested that other areas other than IFG, SMA, and STS are the focus of adaptation-related changes in speech perception. For instance, Rauschecker and Scott (2009) suggest hat the IPL provides an interface "where feed-forward signals from motor preparatory networks in the inferior frontal cortex and premotor cortex can be matched with feedback signals from sensory areas" (p. 722). Increased BOLD-activation was found-albeit at a lowered significance level-for the repeat group in the second run for the contrast [Repeat Run $2>1$ ] $>$ [Imitation Run $2>1$ ]. However, no activation was found in IPL for the imitation group in the second run compared to the repeat group. It is possible that IPL was more active during the training phase for the imitation group and that the current design has not been able to record this activity as the scanner was turned off during training.
The question of which areas are active while participants are acquiring motor experience may be resolved in an online imitation design, for instance in an experiment in which participants are scanned while vocally imitating or repeating a novel speech stream. Such a design may allow for scrutiny of imitation-related activity in IPL, IFG, STS, and SMA.

\section{INTERACTION BETWEEN GROUP AND RUN}

The absolute pattern of results for the interaction effect observed in the behavioral data as well as in the neuroimaging data was not completely in line with our predictions. Namely, while we hypothesized an interaction in participants' performance between Run $\times$ Group, we expected that interaction to be driven by a significant increase in performance in Run 2 for participants who had imitated in contrast to participants who repeated in their own accent. Instead, the interaction in the current data set is driven by a relative decrease in performance for participants in the Repeat as compared to the Imitate Group. Thus, while the overall and relative pattern of results is in line with our predictions, the pattern within the second alone warrants further discussion. 
The first explanation of these results is in terms of the simulation theories discussed in the Introduction. Simulation models presume that imitative motor involvement helps perceivers anticipate other people's actions better by generating forward models (Grush, 2004). These models serves to anticipate others' actions as if they were our own, something which is proposed to be beneficial for ambiguous or noisy signals or actions (Wilson and Knoblich, 2005; Pickering and Garrod, 2007). Simulation models predict that imitation improves perception, and several studies have recently confirmed this prediction for manual actions (Locatelli et al., 2012) and for speech (Adank et al., 2010). Simulation models generally presume that imitation is predominantly covert (and that any overt imitative action is actively suppressed, cf. Baldissera et al., 2001), but it is unclear how the act of overt motor imitation can support perception.

Moreover, recent behavioral research on perceptual learning in speech indicates that listeners adapt to accented speech by updating their internal phoneme representations for the speech sounds in question (e.g., Norris et al., 2003; Evans and Iverson, 2004). Information from speech articulators may be used to inform feed forward models used in the simulation process. Two recent studies support the possibility of such a supporting mechanism. D'Ausilio et al. (2009) demonstrated that repetitive Transcranial Magnetic Stimulation (rTMS) to lip and tongue motor cortex shifted perception of speech toward speech sounds involving these articulators, while Ito et al. (2009) demonstrated that perception of vowel sounds is affected by feedback from facial muscles while speaking these vowels with an altered pronunciation. Information from muscles can therefore, be used to inform perception. This information could be used by the forward models to improve prediction of utterances in the unfamiliar accent. In contrast, in the repeat group no updated information was available from motor neurons in articulation muscles. In turn, this could have resulted in the trend toward poorer comprehension after training in the current experiment.

However, an alternative explanation of the interaction between group and run and the trend toward lower intelligibility judgments in repeat group could be that participants in the repeat group performed a less engaging task. It seems plausible that having to replicate the way in which a sentence is being said is a task that requires more attention and effort than a task in which participants had to pronounce what was being said in their own accent. This possible increased lower engagement in the Repeat group may have had the following two consequences.

First, participants in the Repeat group could have gotten more fatigued and bored than those in the Imitation group. Consequently, participants in the Repeat group may not have been able (or willing) to pay as much attention in the first run. There exists anecdotal and experimental support for the notion that it is harder to maintain attention in unchallenging, monotonous tasks than for cognitively demanding but interesting tasks (see Robertson and O'connell, 2010, for an overview). Generally, behavioral performance deteriorates for longer sustained tasks, and this deterioration is faster for unchallenging tasks (such as repeating compered to imitating). A recent meta-analysis of neuroimaging studies on vigilant attention (i.e., the cognitive function that enables prolonged engagement in intellectually unchallenging, uninteresting activities) identified a network of-mostly right-lateralized-brain regions subserving vigilant attention, including dorsomedial, mid- and ventrolateral prefrontal cortex, anterior insula, parietal areas (intraparietal sulcus, temporoparietal junction), and finally subcortical structures (cerebellar vermis, thalamus, putamen, and midbrain) (Langner and Eickhoff, 2013). Note that our network of areas displaying the interaction effect ([Imitation Run 2>1] > [Repeat Run $2>1$ ]) was exclusively left-lateralized and does not appear to overlap with the network identified by Langner and Eickhoff. Furthermore, inspecting of the reverse contrast ([Repeat Run $2>1]>$ [Imitation Run $2>1]$ ) at a less stringent significance level indicated involvement of left IPL, whereas Langner and Eickhoff's analysis showed no clusters in the left parietal lobe.

Second, participants in the Repeat group performed a task that may have not allowed them to engage with the speaker of the accent as much as participants in the Imitation group. This decreased engagement could then have made them less willing to put as much effort into understanding the accented sentences in the second run as in the first run. This notion is speculative, but is supported by an experiment on the effect of imitating a target's (such as a speaker) behavior on the perception of the social characteristics of that target. In a within-subject design, Adank et al. (2013) asked a group of participants to listen to sentences spoken by two speakers of a regional accent (Glaswegian) of British-English. Next, they repeated the sentences spoken by one of the Glaswegian speakers in their own accent, and subsequently participants imitated sentences spoken by the second Glaswegian speaker. The order of repeating and imitating was counterbalanced across participants. After each repeating or imitation session, participants completed a questionnaire probing the speakers' perceived power, competence, and social attractiveness. Imitating had a positive effect on the perceived social attractiveness of the speaker compared to repeating. The authors explained the positive results of imitating by stating that the act of imitating another's accent makes the speaker part of participants' social in-group in a way that repeating does not. Since people are more positively biased toward people in their in-group than those outside (Brewer, 1979), such ingroup favoritism then made the speaker seem more subjectively pleasant. However, it is unclear whether a comparable effect of imitation on perception of the speaker would also occur for the constructed accent used in our study. Hearing accented speech automatically invokes attitudes associated with speakers of the accent (Giles, 1970; Bishop et al., 2005; Coupland and Bishop, 2007) and it seems unlikely that constructed accents are associated with specific language attitudes as is the case for existing accents.

The issue of differences in engagement with the task across groups issue may be addressed in future studies by explicitly matching training tasks for "level of interest." One way to achieve this would be to create two different constructed accents that are matched for intelligibility and have participants repeat sentences for one of the accents and imitate for the other accent in a withinsubject design. Subsequently, their intelligibility of both accents 
could be tested to verify that imitation had a positive effect on the intelligibility of the imitated constructed accent. However, we chose not to take this route in the present study, as we aimed to replicate the design in Adank et al. (2010) as closely as possible using an fMRI design. Yet, future studies could, for instance, pre-test a variety of tasks on how much they are perceived to be equally interesting or engaging by participants or use multiple constructed accents.

A final explanation for the pattern in the behavioral results could be that the behavioral task used in the experiment, perhaps in combination with the presence of continuous scanner noise, did not accurately reflect the extent to which participants' performance changed over the two runs. Our earlier behavioral study described in Adank et al. (2010) used the standard SRT procedure (which is the same as described for the hearing test in the Materials and Methods section), and it seems plausible that this test provides a more fine-grained measure of intelligibility processing than the test used in the scanner. Adank et al.'s SRT procedure involved overt vocal responses, which was not optimal given our fMRI design. Future studies should thus, consider using a more fine-grained behavioral task, possibly in combination with a sparse sampling design (Hall et al., 1999).

\section{REFERENCES}

Adank, P. (2012). The neural bases of difficult speech comprehension and speech production and their overlap: two Activation Likelihood Estimation (ALE) meta-analyses. Brain Lang. 122, 42-54. doi: 10. 1016/j.bandl.2012.04.014

Adank, P., Davis, M., and Hagoort, P. (2012). Neural dissociation in processing noise and accent in spoken language comprehension. Neuropsychologia 50, 77-84. doi: 10.1016/j.neuropsychologia. 2011.10.024

Adank, P., and Devlin, J. T. (2010). Online plasticity in spoken sentence comprehension: adapting to timecompressed speech. Neuroimage 49, 1124-1132. doi: 10.1016/j.neuro image.2009.07.032

Adank, P., Evans, B. G., StuartSmith, J., and Scott, S. K. (2009). Comprehension of familiar and unfamiliar native accents under adverse listening conditions. J. Exp. Psychol. Hum. Percept. Perform. 35, 520-529. doi: 10.1037/a00 13552

Adank, P., Hagoort, P., and Bekkering, H. (2010). Imitation improves language comprehension. Psychol. Sci. 21, 1903-1909. doi: 10.1177/0956 797610389192

Adank, P., Stewart, A. J., Connell, L., and Wood, J. (2013). Accent imitation positively affects accent attitudes. Front. Psychol. 4:280. doi: 10. 3389/fpsyg.2013.00280
Aglioti, S. M., Cesari, P., Romani, M., and Urgesi, C. (2008). Action anticipation and motor resonance in elite basketball players. Nat. Neurosci. 11, 1109-1116. doi: 10. 1038/nn.2182

Alario, F. X., Chainay, H., Lehericy, S., and Cohen, L. (2006). The role of the supplementary motor area (SMA) in word production. Brain brainres.2005.11.104

Ashburner, J., and Friston, K. J. (1997). Multimodal image coregistration and partitioning - a unified framework. Neuroimage 6, 209-217. doi: 10.1006/nimg.1997.0290

Baldissera, F., Cavallari, P., Craighero, L., and Fadiga, L. (2001). Modulation of spinal excitability during observation of hand actions in humans. Eur. J. Neurosci. 13, 190-194. doi: 10.1046/j.0953816x.2000.01368.x

Bishop, H., Coupland, N., and Garrett, P. (2005). Conceptual accent evaluation: thirty years of accent prejudice in the UK. Acta Linguist. Hafniensia. Int. J. Linguist. 37, 131-154. doi: 10. 1080/03740463.2005.10416087

Blank, S. C., Scott, S. K., Murphy, K., Warburton, E., and Wise, R. J. S. (2002). Speech production: wernicke, broca and beyond. Brain 125, 1829-1838. doi: 10.1093/brain/ awf191

Blesser, B. (1972). Speech perception under conditions of spectral transformation. I. Phonetic Res. 1076, 129-143. doi: 10.1016/j.

\section{CONCLUSION}

Previous studies (e.g., Davis and Johnsrude, 2003; Adank, 2012) have shown that processing of intelligible speech involves neural substrates associated with speech production and speech perception. This study adds to a growing body of literature showing that processing of intelligible speech involves sensorimotor processes. However, further research is required to establish in what manner overt imitation of speech contributes to these sensorimotor processes in challenging listening situations. Ideally, future studies involving imitation related-training should make a point of explicitly disentangling the possible contribution of factors such as participant (dis)engagement and listening environment. Only by addressing these issues can the contribution of imitative actions to speech perception be elucidated.

\section{ACKNOWLEDGMENTS}

We wish to thank Pascal de Water and Paul Gaalman for technical assistance and Ivan Toni for useful comments on the design of the study. The study was supported by the Dutch Organization for Scientific Research (NWO) through a VENI grant 016094-053 to Shirley-Ann Rueschemeyer and a VICI grant 453-05-001 to Harold Bekkering.

characteristics. J. Speech Hear. Res. 15, 5-41.

Boersma, P., and Weenink, D. (2003). Praat: doing Phonetics by Computer. Available online at: http://www.praat.org

Brett, M., Anton, J.-L., Valabregue, R., and Poline, J.-B. (2002). Region of interest analysis using an SPM toolbox. Neuroimage 167, 479.

Brewer, M. B. (1979). In-group bias in minimal intergroup situation: a cognitive-motivational analysis. Psychol. Bull. 86, 307-324. doi: 10. 1037/0033-2909.86.2.307

Callan, D. E., Callan, A. M., Gamez, M. Sato, M., and Kawato, M. (2010). Premotor cortex mediates perceptual performance. Neuroimage 51, 844-858. doi: 10.1016/j.neuro image.2010.02.027

Calvo-Merino, B., Glaser, D. E., Grezes, J., Passingham, R. E., and Haggard, P. (2005). Action observation and acquired motor skills. Cereb. Cortex 15, 1243-1249. doi: 10.1093/cercor/bhi007

Coupland, J., and Bishop, H. (2007). Ideologised values for British accents. J. Socioling. 11, 74-93. doi: $\quad 10.1111 /$ j.1467-9841.2007. 00311.x

Crinion, J. T., and Price, C. J. (2005). Right anterior superior temporal activation predicts auditory sentence comprehension following aphasic stroke. Brain 128, 2858-2871. doi: 10.1093/brain/ awh659
D’Ausilio, A., Pülvermüller, F., Salmas, P., Bufalari, I., Begliomini, C., and Fadiga, L. (2009). The motor somatotopy of speech perception. Curr. Biol. 19, 381-385. doi: 10.1016/j.cub.2009.01.017

Davis, M. H., and Johnsrude, I. S. (2003). Hierarchical processing in spoken language comprehension. J. Neurosci. 23, 3423-3431.

Dupoux, E., and Green, K. (1997). Perceptual adjustment to highly compressed speech: effects of talker and rate changes. J. Exp. Psychol. Hum. Percept. Perform. 23, 914-927. doi: 10.1037/0096-1523.23.3.914

Eickhoff, S. B., Stephan, K. E., Mohlberg, H., Grefkes, C., Fink, G. R., Amunts, K., et al. (2005). A new SPM toolbox for combining probabilistic cytoarchitectonic maps and functional imaging data. Neuroimage 25, 1325-1335. doi: 10. 1016/j.neuroimage.2004.12.034

Eisner, F., McGettigan, C., Faulkner, A., Rosen, S., and Scott, S. K. (2010). Inferior frontal gyrus activation predicts individual differences in perceptual learning of cochlearimplant simulations. J. Neurosci. 30, 7179-7186. doi: 10.1523/JNEURO SCI.4040-09.2010

Evans, B. G., and Iverson, P. (2004). Vowel normalization for accent: an investigation of best exemplar locations in northern and southern British English sentences. J. Acoust. Soc. Am. 115, 352-361. doi: 10.1121/ 1.1635413 
Fridriksson, J., Moser, D., Ryalls, J., Bonilla, L., Rorden, C., and Baylis, G. (2009). Modulation of frontal lobe speech areas associated with the production and perception of speech movements. J. Speech Lang. Hear. Res. 52, 812-819. doi: $\quad 10.1044 / 1092-4388(2008 /$ 06-0197)

Friston, K. J., Holmes, A. P., Poline, J. B., Grasby, P. J., Williams, S. C., Frackowiak, R. S., et al. (1995). Analysis of fMRI time-series revisited. Neuroimage 2, 45-53. doi: 10. 1006/nimg. 1995.1007

Giles, H. (1970). Evaluative reactions to accents. Educ. Rev. 22, 211-227. doi: 10.1080/0013191700220301

Grafton, S. (2009). Embodied cognition and the simulation of action to understand others. Ann. N.Y. Acad. Sci. 1156, 97-117. doi: 10.1111/j. 1749-6632.2009.04425.x

Grush, R. (2004). The emulation theory of representation: motor control, imagery, and perception. Behav. Brain Sci. 27, 377-435. doi: 10.1017/ S0140525X04000093

Hall, D. A., Haggard, M. P., Akeroyd, M. A., Palmer, A. R., Summerfield, A. Q., Elliot, M. R., et al. (1999). "Sparse" temporal sampling in auditory fMRI. Hum. Brain Mapp. 7, 213-223. doi: 10.1002/(SICI) 1097-0193(1999)7:3<213::AID-HB M5>3.0.CO;2-N

IPA. (1999). Handbook of the International Phonetic Association: A guide to the use of the International Phonetic Alphabet. Cambridge: Cambridge University Press.

Ito, T., Tiede, M., and Ostry, D. J. (2009). Somatosensory function in speech perception. Proc. Natl. Acad. Sci. 106, 1245-1248. doi: 10.1073/pnas.0810063106

Knoblich, G., and Sebanz, N. (2006). The social nature of percepton and action. Curr. Dir. Psychol. Sci. 15, 99-104. doi: 10.1111/j.0963-7214. 2006.00415.x

Lahav, A., Saltzman, E., and Schlaug, G. (2007). Action representation of sound: audiomotor recognition network while listening to newly acquired actions. J. Neurosci. 27, 308-314. doi: 10.1523/JNEUROSCI.4822-06.2007

Langner, R., and Eickhoff, S. B. (2013). Sustaining attention to simple tasks: a meta-analytic review of the neural mechanisms of vigilant attention. Psychol. Bull. 139, 870-900. doi: 10.1037/a0030694
Locatelli, M., Gatti, R., and Tettamanti, M. (2012). Training of manual actions improves language understanding of semantically related action sentences. Front. Psychol. 3:547. doi: 10.3389/fpsyg.2012. 00547

Londei, A., D’Ausilio, A., Basso, D., Sestieri, C., Gratta, C. D., Romani, G. L., et al. (2009). Sensory-motor brain network connectivity for speech comprehension. Hum. Brain Mapp. 31, 567-580. doi: 10.1002/ hbm. 20888

Narain, C., Scott, S. K., Wise, R. J. S., Rosen, S., Leff, A., Iversen, S. D., et al. (2003). Defining a leftlateralized response specific to intelligible speech using fMRI. Cereb. Cortex 13, 1362-1368. doi: 10.1093/ cercor/bhg083

Norris, D., McQueen, J. M., and Cutler, A. (2003). Perceptual learning in speech. Cogn. Psychol. 47, 204-238. doi: 10.1016/S0010-0285 (03)00006-9

Obleser, J., and Kotz, S. A. (2010). Expectancy constraints in degraded speech modulate the language comprehension network. Cereb. Cortex 20, 633-640. doi: 10.1093/cercor/bhp 128

Obleser, J., Meyer, L., and Friederici, A. D. (2011). Dynamic assignment of neural resources in auditory comprehension of complex sentences. Neuroimage 56, 2310-2320. doi: 10.1016/j.neuroimage.2011.03.035

Obleser, J., Wise, R. J. S., Dresner, M. A., and Scott, S. K. (2007). Functional integration across brain regions improves speech perception under adverse listening conditions. J. Neurosci. 27, 2283-2289. doi: 10.1523/JNEUROSCI.4663-06.2007

Peelle, J. E., Troiani, V., Wingfield, A., and Grossman, M. (2010). Neural processing during older adults' comprehension of spoken sentences: age differences in resource allocation and connectivity. Cereb. Cortex 20, 773-782. doi: 10.1093/cercor/bhp142

Pickering, M. J., and Garrod, S. (2007). Do people use language production to make predictions during comprehension? Trends Cogn. Sci. 11, 105-110. doi: 10.1016/j.tics.2006. 12.002

Plomp, R., and Mimpen, A. M. (1979). Speech reception threshold for sentences as a function of age and noise level. J. Acoust. Soc. Am. 66, 1333-1342. doi: 10.1121/1.383554
Rauschecker, J. P., and Scott, S. K. (2009). Maps and streams in the auditory cortex: nonhuman primates illuminate human speech processing. Nat. Neurosci. 12, 718-724. doi: 10.1038/nn.2331

Robertson, I. H., and O'connell, R. G. (2010). "Vigilant attention," in Attention and Time, eds A. C. Nobre and J. T. Coull (Oxford: Oxford University Press), 79-88.

Rodd, J. M., Davis, M. H., and Johnsrude, I. S. (2005). The neural mechanisms of speech comprehension: fMRI studies of semantic ambiguity. Cereb. Cortex 15, 1261-1269. doi: 10.1093/cercor/ bhi009

Rodd, J. M., Longe, O. L., Randall, B., and Tyler, L. K. (2010). The functional organisation of the fronto-temporal language system: evidence from syntactic and semantic ambiguity. Neuropsychologia 48, 1324-1335. doi: 10.1016/j.neuro psychologia.2009.12.035

Rorden, C., and Brett, M. (2000). Stereotaxic display of brain lesions. Behav. Neurol. 12, 191-200.

Scott, S. K., Blank, S. C., Rosen, S., and Wise, R. J. S. (2000). Identification of a pathway for intelligible speech in the left temporal lobe. Brain 123, 2400-2406. doi: 10.1093/brain/123.12.2400

Shannon, R. V., Zeng, F. G., Kamath, V., Wygonski, J., and Ekelid, M. (1995). Speech recognition with primarily temporal cues. Science 270 , 303-304. doi: 10.1126/science.270. 5234.303

Skipper, J. I., Nusbaum, H. C., and Small, S. L. (2006). "Lending a helping hand to hearing: another motor theory of speech perception," in Action to Language Via the Mirror Neuron System, ed M. A. Arbib (Cambridge, MA: Cambridge University Press), 250-285. doi: 10.1017/CBO9780511541599.009

Tremblay, P., and Gracco, V. L. (2009). Contribution of the pre-SMA to the production of words and non-speech oral motor gestures, as revealed by repetitive transcranial magnetic stimulation (rTMS). Brain Res. 1268, 112-124. doi: 10.1016/j.brainres.2009.02.076

Tremblay, P., and Small, S. L. (2011). On the context-dependent nature of the contribution of the ventral premotor cortex to speech perception. Neuroimage 57, 1561-1571. doi: 10.1016/j.neuroimage.2011.05.067
Van Wijngaarden, S. J., Steeneken, H. J., and Houtgast, T. (2002). Quantifying the intelligibility of speech in noise for non-native talkers. J. Acoust. Soc. Am. 112 3004-3013. doi: 10.1121/1.1512289

Venezia, J. H., Saberi, K., Chubb, C., and Hickok, G. (2012). Response bias modulates the speech motor system during syllable discrimination. Front. Psychol. 3:157. doi: 10.3389/fpsyg.2012.00157

Wilson, M., and Knoblich, G. (2005). The case for motor involvement in perceiving conspecifics. Psychol. Bull. 131, 460-473. doi: 10.1037/0033-2909.131.3.460

Wilson, S. M., and Iacoboni, M. (2006). Neural responses to non-native phonemes varying in producibility: evidence for the sensorimotor nature of speech perception. Neuroimage 33, 316-325. doi 10.1016/j.neuroimage.2006.05.032

Wong, P. C. M., Uppanda, A. K., Parrish, T. B., and Dhar, S. (2008). Cortical mechanisms of speech perception in noise. J. Speech Lang. Hear. Res. 51, 1026-1041. doi: 10.1044/1092-4388(2008/075)

Conflict of Interest Statement: The authors declare that the research was conducted in the absence of any commercial or financial relationships that could be construed as a potential conflict of interest.

Received: 20 April 2013; accepted: 12 September 2013; published online: 04 October 2013.

Citation: Adank P, Rueschemeyer S-A and Bekkering $H$ (2013) The role of accent imitation in sensorimotor integration during processing of intelligible speech. Front. Hum. Neurosci. 7:634. doi: 10.3389/fnhum.2013.00634

This article was submitted to the journal Frontiers in Human Neuroscience. Copyright () 2013 Adank, Rueschemeyer and Bekkering. This is an open-access article distributed under the terms of the Creative Commons Attribution License (CC BY). The use, distribution or reproduction in other forums is permitted, provided the original author(s) or licensor are credited and that the original publication in this journal is cited, in accordance with accepted academic practice. No use, distribution or reproduction is permitted which does not comply with these terms. 


\section{APPENDIX}

Table A1 | Test sentences from the Speech Reception Threshold corpus (Plomp and Mimpen, 1979).

\section{Nr. Standard Dutch}

1 De bal vloog over de schutting

2 Morgen wil ik maar één liter melk

3 Deze kerk moet gesloopt worden

4 De spoortrein was al gauw kapot

5 De nieuwe fiets is gestolen

6 Zijn manier van werken ligt mij niet

7 Het slot van de voordeur is kapot

8 Dat hotel heeft een slechte naam

9 De jongen werd stevig aangepakt

10 Het natte hout sist in het vuur

11 Zijn fantasie kent geen grenzen

12 De aardappels liggen in de schuur

13 Alle prijzen waren verhoogd

14 Zijn leeftijd ligt boven de dertig

15 Het dak moet nodig hersteld worden

16 De kachel is nog steeds niet aan

17 Van de viool is een snaar kapot

18 De tuinman heeft het gras gemaaid

19 De appels aan de boom zijn rijp

20 Voor het eerst was er nieuwe haring

21 Het loket bleef lang gesloten

22 Er werd een diepe kuil gegraven

23 Zijn gezicht heeft een rode kleur

24 Het begon vroeg donker te worden

25 Het gras was helemaal verdroogd

26 Spoedig kwam er een einde aan

27 leder half uur komt hier een bus langs

28 De bel van de voordeur is kapot

29 De wind waait vandaag uit het westen

30 De slang bewoog zich door het gras

31 De kamer rook naar sigaren

32 De appel had een zure smaak

33 De trein kwam met een schok tot stilstand

\section{Accented Dutch}

De baal vlog offer de schuuttieng

Moorgen wiel iek mar èn litter meelk

Desse keerk mut geslopt woorden

De sportreen waas aal goew kaappoot

De niwwe fits ies gestollen

Zeen mannir vaan weerken liegt mee nit

Het sloot vaan de vordur ies kaappoot

Daat hotteel heft ' $n$ sleechte nam

De joongen weerd steffig angepaakt

Het naatte hoet siest ien het vur

Zeen faantassih keent gèn greenzen

De ardaappels liegen ien de schur

Aalle preezen warren verhogt

Zeen lèfteed liegt boffen de deertieg

Het daak mut noddieg heersteeld woorden

De kaachel ies noog stèds nit an

Vaan de vij-jol ies ' $n$ snar kaappoot

De tuunmaan heft het graas gemajt

De aappels an de bom zeen reep Vor het erst waas eer niwwe harrieng

Het lokkeet blef laang geslotten

Eer weerd ' $n$ dippe koel gegraffen

Zeen geziecht hèft 'n rodde klur

Het beggoon vrug doonker te woorden

Het graas waas hèllemal verdrogt Spuddieg kwaam eer ' $n$ eende an Idder haalf ur koomt hir ' $n$ buus laangs

De beel vaan de vordur ies kaappoot

De wiend wajt vaandag uut het weesten

De slaang bewog ziech dor het graas

De kammer rok nar siggarren

De aappel haad ' $n$ zurre smak

De treen kwaam meet 'n schook toot stielstaand

\section{Table A1 | Continued}

\section{Nr. Standard Dutch}

34 De koeien werden juist gemolken

35 Het duurt niet langer dan een minuut

36 De grijze lucht voorspelt regen

$37 \mathrm{Hij}$ kon de hamer nergens vinden

38 Deze berg is nog niet beklommen

39 De bel van mijn fiets is kapot

40 De auto heeft een lekke band

41 Het moeilijke werk bleef liggen

42 Het vliegtuig vertrekt over een uur

43 De jongens vechten de hele dag

44 De schoenen moeten verzoold worden

Accented Dutch

De kujjen weerden juust gemoolken

Het durt nit laanger daan 'n minnut

De greeze luucht vorspeelt règgen

Hee koon de hammer neergens vienden

Desse beerg ies noog nit bekloommen

De beel vaan meen fits ies kaappoot

De oetoh hèft 'n leekke baand

Het muj-leekke weerk blef lieggen

ret vligtuug vertreekt offer 'n ur

De joongens veechten de hèlle daag

De schunnen mutten verzold woorden

45 In de krant staat vandaag niet veel len de kraant stat vaandag nit vèl nieuws

46 Door de neus ademen is beter

47 Het kind was niet in staat te spreken

niws

Dor de nus addemmen ies better

Het kiend waas nit ien stat te sprekken

48 De witte zwaan dook onder wate

49 Hij nam het pak onder zijn arm

50 Gelukkig sloeg de motor niet af

51 De leraar gaf hem een laag cijfer

52 Het huis brandde tot de grond toe af

De wiette zwan dok oonder watter

Hee naam het paak oonder zeen aarm

Geluukkieg slug de mottor nit aaf

De lèrrar gaaf heem 'n lag seeffer

Het huus braande toot de groond tuh aaf

53 De foto is mooi ingelijst

De fotto ies moi iengeleest

54 Mijn broer gaat elke dag fietsen

Meen brur gat eelke daag fitsen

55 Een kopje koffie zal goed smaken

Een koopje kooffih zaal gud smakken

56 De schrijver van dit boek is dood

57 Zij heeft haar proefwerk slecht gemaakt

58 De sigaar ligt in de asbak

De schreeffer vaan diet buk ies dot

Zee heft har prufweerk sleecht gemakt

De siggar liegt ien de aasbaak

59 De appelboom stond in volle bloei De aappelbom stoond ien voolle bluj

60 Er wordt in dit land geen rijst verbouwd

61 Hij kan er nu eenmaal niets aan doen

62 De kleren waren niet gewassen

63 Het gedicht werd voorgelezen

64 Haar gezicht was zwart van het vuil

65 De letters stonden op hun kop
Eer woordt ien diet laand gèn reest verbuwd

Hee kaan eer nuh ènmal nits an dun

De klerren warren nit gewaassen Het gediecht weerd vorgelèssen

Har geziecht waas zwaart vaan het vuul

De leetters stoonden oop huun koop 


\section{Table A1 | Continued}

\section{Nr. Standard Dutch}

\section{Accented Dutch}

66 De groene appels waren erg zuur De grunne aappels warren eerg zur

67 In het gebouw waren vier liften len het geboew warren vir lieften

68 Lopen is gezonder dan fietsen

69 Het lawaai maakte hem wakker

70 Mijn buurman heeft een auto gekocht

71 Als het flink vriest kunnen we schaatsen

72 De kast was een meter verschoven

73 Oude meubels zijn zeer in trek

74 De portier ging met vakantie

75 De lantaarn gaf niet veel licht meer

76 Door zijn snelheid vloog hij uit de bocht

77 Het is hier nog steeds veel te koud

78 De oude man was kaal geworden

79 De bomen waren helemaal kaal

80 Rijden onder invloed is strafbaar Loppen ies gezoonder daan fitsen Het lawwai makte heem waakker Meen burmaan heft 'n oetoh gekoocht

Aals het flienk frist kuunnen we schatsen

De kaast waas ' $n$ metter verschoffen

Oede mubbels zeen zèr ien treek De poortir gieng meet vaakkaantih De laantarn gaaf nit vèl liecht mer

Door zeen sneelheed vlog hee uut de boocht

Het ies hir noog steds vèl te koed

De oede maan waas kal gewoorden

De bommen warren hèllemal llemal kal

Reedden oonder ienvlud ies straafbar

81 Onze bank geeft vijf procent rente Oonze baank geft veef prosseent reente

82 Het verslag in de krant is kort Het verslaag ien de kraant ies koort

83 In de vijver zwemmen veel vissen len de veeffer zweemmen vel viessen

84 Honden mogen niet in het Hoonden moggen nit ien het gebouw geboew

85 Een flinke borrel zal mij goed doen Een flienke boorrel zaal mee gud dun

86 Gisteren waaide het nog harder Giesteren wajde het noog haarder

87 Het meisje stond lang te wachten Het meesje stoond laang te waachten

88 De volgende dag kwam hij ook niet

89 Het geschreeuw is duidelijk hoorbaar

90 Eindelijk kwam de trein op gang

91 De grote stad trok hem wel aan

92 De bus is vandaag niet op tijd

93 Onze dochter speelt goed blokfluit

94 Ook in de zomer is het hier koel

95 Zij moesten vier uur hard werken

96 Niemand kan de Fransman verstaan

De voolgende daag kwaam hee ok nit

Het geschrew ies duudeleek horbar

Eendeleek kwaam de treen oop gaang

De grotte staad trook heem weel an

De buus ies vaandag nit oop teed Oonze doochter spèlt gud blookfluut

Ok ien de zommer ies het hir kul Zee musten vir ur haard weerken Nimmaand kaan de Fraansmaan verstan

Only vowels bearing primary or secondary lexical stress were included in the conversion of the orthography.
Table A2 | Training sentences.

Nr. Standard Dutch Accented Dutch

1 Architecten hebben een beroep

2 Asperges zijn groenten

Aarchitteecten heeben een berup

3 Aardappels worden geschild

Aaspeerges zeen grunten

4 Bananen zijn fruit

5 Bijen vliegen rond op zoek naar voedsel

6 Bevers bouwen dammen in de rivier

7 Beren hebben vier poten

8 Bisschoppen dragen kleren

9 Biefstukken worden verkocht door slagers

10 Blikopeners kunnen in winkels gekocht worden

11 Bromfietsen rijden op de weg

12 Chirurgen moeten lang studeren

13 Druiven zijn eetbaar

14 Ezels dragen zware vrachten

15 Ezels kunnen koppig zijn

16 Forellen hebben schubben

17 Ganzen kunnen ver vliegen

18 Haaien hebben sterke tanden

Ardaappels woorden geschield

Bannannen zen fruut

Beej-jen vliggen roond oop zuk nar vudsel

Beffers buwwen damen ien de rivvir

Berren heeben vir potten

Biesschopen draggen klerren

Bifstuukken woorden verkoocht dor slaggers

Bliekoppeners kuunen ien wienkels gekoocht woorden

Broomfitsen reeden oop de weeg

Chieruurgen mutten laang studderren

Druuven zeen etbar

Essels draggen zwarre vraachten Essels kuunen kooppieg zeen

Forrelen heeben schuubben

Gaanzen kuunen veer vliggen

Hajjen heeben steerke taanden

19 Heggenscharen worden in de tuin Heegenscharren woorden ien de gebruikt

20 Kapiteins voeren het bevel op schepen

21 Kasten zijn van hout

22 Kroketten zijn gefrituurd

23 Lammetjes komen van schapen

24 Lepels worden gebruikt voor het eten van soep

25 Leeuwen hebben manen

26 Luipaarden hebben een vacht

27 Makrelen ademen door kieuwen

28 Messen worden gebruikt als keukengerei

29 Monniken wonen in een klooster

30 Nachtegalen hebben veren

31 Ooms zijn deel van de familie

32 Otters kunnen goed zwemmen

33 Pinguïns eten veel vis toen gebroekt

Kaapitteins vurren het bevveel oop scheppen

Kaasten zeen vaan hoet Krokkeetten zeen gefritturd Lametjes kommen vaan schappen Leppels woorden gebroekt vor het etten vaan sup

Lewwen heeben mannen Luuparden heeben ' $n$ vaacht Maakrellen addeemen dor kiwwen

Meessen woorden gebroekt aals kukkengeree

Moonnieken wonnen ien 'n kloster

Naachtegallen heeben verren Oms zeen del vaan de fammillih

Ooters kuunen gut zweemen

Piengiens etten vel vies

34 Presidenten werken in de politiek

35 Ratelslangen kruipen op hun buik

36 Roodborstjes hebben een snave

37 Schuurtjes worden gebruikt voor opslag

38 Slagers hebben winkels

39 Sloffen worden gemaakt in een fabriek
Pressideenten weerken ien de pollittik

Rattelslaangen kroepen oop huun boek

Rodboorstjes heeben een snaffel Schurtjes woorden gebroekt vor oopslaag

Slaggers heeben wienkels

Sloofen woorden gemakt ien 'n fabbrik 
Table A2 | Continued

\begin{tabular}{lll} 
Nr. & Standard Dutch & Accented Dutch \\
\hline 40 & Tantes zijn altijd vrouwen & Taantes zeen aalteed vroewen \\
41 & Tijgers hebben een staart & Teegers heeben 'n start \\
42 & Tomaten groeien aan planten & Tommatten grujjen an plaanten \\
43 & Vaders zijn ouders & Vadders zeen oeders \\
44 & Vlinders hebben voelsprieten & Vlienders heeben vulspritten \\
45 & Wandelschoenen zijn & Waandelschunnen zeen \\
& gefabriceerde goederen & gefaabrisserde gudderen \\
46 & Wijflessen hebben een kurk & Weenfleessen heeben 'n kuurk \\
47 & Wetenschappers moeten lang & Wettenschaapers mutten laang \\
& studeren & studderren \\
48 & Wortels groeien in een moestuin & Woortels grujjen ien 'n mustuun
\end{tabular}

Only vowels bearing primary or secondary lexical stress were included in the conversion of the orthography.

Table A3 | Hearing test sentences, spoken in Standard Dutch.

\begin{tabular}{|c|c|c|}
\hline Nr. & Standard Dutch & Key words \\
\hline 1 & Het regent al de hele dag & regent al hele dag \\
\hline 2 & De schaatsen zijn in het vet gezet & schaatsen zijn vet gezet \\
\hline 3 & In juni zijn de dagen het langst & juni zijn dagen langst \\
\hline 4 & De bakkers bezorgen vandaag niet & bakkers bezorgen vandaag niet \\
\hline 5 & Hij rookte zijn sigaret op & rookte zijn sigaret op \\
\hline 6 & Het was heel stil in de duinen & was heel stil duinen \\
\hline 7 & $\begin{array}{l}\text { Door zijn haast maakte hij veel } \\
\text { fouten }\end{array}$ & Door haast veel fouten \\
\hline 8 & De kat likt het schoteltje leeg & kat likt schoteltje leeg \\
\hline 9 & De hond blafte de hele nacht & hond blafte hele nacht \\
\hline 10 & $\begin{array}{l}\text { Het tempo lag voor hem veel te } \\
\text { hoog }\end{array}$ & tempo hem veel hoog \\
\hline 11 & Lawaai maakt je op den duur doof & Lawaai maakt duur doof \\
\hline 12 & Moeizaam klom de man naar boven & Moeizaam klom man boven \\
\hline 13 & Hij probeerde het nog een keer & Hij probeerde nog keer \\
\hline 14 & Toch lijkt me dat een goed voorstel & Toch lijkt goed voorstel \\
\hline 15 & Dat was voor hem een bittere pil & Dat hem bittere pil \\
\hline 16 & De nieuwe zaak was pas geopend & nieuwe zaak pas geopend \\
\hline 17 & De rivier trad buiten haar oevers & rivier trad buiten oevers \\
\hline 18 & De biefstuk was vandaag erg mals & biefstuk vandaag erg mals \\
\hline 19 & Op het gras mag men niet lopen & gras mag niet lopen \\
\hline 20 & De trein vertrekt over twee uur & trein vertrekt twee uur \\
\hline 21 & De kat van de buren is weg & kat van buren weg \\
\hline 22 & De wagen reed snel de berg af & wagen reed snel berg \\
\hline 23 & ledereen genoot van het uitzicht & ledereen genoot van uitzicht \\
\hline 24 & Steile trappen zijn gevaarlijk & Steile trappen zijn gevaarlijk \\
\hline 25 & De zon gaat in het westen onder & zon gaat westen onder \\
\hline 26 & De zak zat vol oude rommel & zak vol oude rommel \\
\hline 27 & Zij werd misselijk van het rijden & Zij werd misselijk rijden \\
\hline 28 & $\begin{array}{l}\text { Het licht in de gang brandt nog } \\
\text { steeds }\end{array}$ & licht gang brandt steeds \\
\hline 29 & $\begin{array}{l}\text { In de kerk werd mooi orgel } \\
\text { gespeeld }\end{array}$ & kerk mooi orgel gespeeld \\
\hline 30 & $\begin{array}{l}\text { De jongens gingen er gauw } \\
\text { vandoor }\end{array}$ & jongens gingen gauw vandoor \\
\hline
\end{tabular}

